\title{
Meaningfulness and Coherence? Experiences Among Young Soldiers in the Swedish Armed Forces'
}

I Gunnar Gillberg ${ }^{2}$

PhD, Department of Sociology and Work Science, University of Gothenburg

ORCID: https://orcid.org/0000-0001-5997-0472

\section{Roland Kadefors}

Professor, Department of Sociology and Work Science, University of Gothenburg ORCID: https://orcid.org/0000-0002-5003-0967

I Jan Holmer

Professor, Department of Sociology and Work Science, University of Gothenburg ORCID: https://orcid.org/0000-0001-8938-4722

I Anders Östebo

Project Manager, Department of Sociology and Work Science, University of Gothenburg ORCID: https://orcid.org/0000-0002-7059-4495

\begin{abstract}
The twofold aim of the present study was to try to understand why young recruits to the Swedish Armed Forces chose a military career rather than a civilian one, and how their expectations were met when confronted with the realities of life as a soldier or marine. The study material consisted of 57 interviews with 37 young recruits; the interviews were carried out at units representing different branches of the Armed Forces. The interviews were semi-structured, transcribed, and categorized. It was found that the desire to remain employed as a soldier or marine in the Swedish Armed Forces is based on a set of individual and organizational factors: the selection process, the sense of meaningfulness and organizational coherence, the safety offered, and the salutogenic nature of military working life. The recruits are part of a system that offers good work conditions in return for taxing and stressful work assignments.
\end{abstract}

\section{KEYWORDS}

Military / soldiers / young adults / work life / salutogenesis / generative mechanisms (meaningfulness / fellowship / stability) / career

\section{Introduction}

he starting point for the present study was to investigate why young people apply to the Armed Forces and what factors influence their choice to stay or terminate their employment. This can be understood as an interest in how organizational conditions (at different levels) and agency (intentional actions and strategies) interact when young

\footnotetext{
${ }^{1}$ You can find this text and its DOI at https://tidsskrift.dk/njwls/index.

${ }^{2}$ Corresponding author: Gunnar Gillberg, Department of Sociology and Work Science, University of Gothenburg, Box 720, SE-405 30 Gothenburg, Sweden. E-mail: gunnar.gillberg@socav.gu.se.
} 
adults are about to establish themselves in the Armed Forces. In contemporary working life, which is characterized by individualized responsibility and personally driven employability, it is of interest to understand the motives underlying the choice of the Armed Forces as an employer. The general public often perceives the Armed Forces as 'a static, hierarchical, and "old-fashioned" organization that lacks modern organizational structures and innovation' (Swedish Armed Forces 2011). However, the Armed Force have sought to promote themselves as an 'entrepreneurial and inclusive organization offering opportunities for personal, professional and corporal development' (Strand 2019). Taking into account the problems and time needed to manage organizational change in large organizations characterized by a high degree of professionalism, a mismatch between expectations and reality is likely. Is this what new recruits have experienced?

The present article thus addresses two basic questions: Why do young people apply to the Armed Forces? What are the mechanisms underlying the choice to remain employed in the Armed Forces? However, these fundamental questions presuppose an examination of the organizational and institutional conditions that characterize the Armed Forces.

The article begins by discussing the situation of young adults in the labor market and providing an overview of the research available on young adults in the Armed Forces. It also presents some characteristics of the organizational conditions of the Armed Forces as a workplace. This is followed by a theoretical framework, some conceptual conditions, and methods. The methodology is based on a realistic view of the relationship between structure and agency, and an interpretation of individualization as an expression of increased individual responsibility for a number of issues in society that were previously perceived as a collective responsibility, such as employability and stability on the labor market. Finally, the results of the interviews are described, along with an analysis and discussion of the generative mechanisms activated when young adults negotiate their opportunities within the Armed Forces.

\section{Young adults and the labor market}

There is an extensive body of research on how young adults relate to the labor market and to their occupational choices (for reviews, see, e.g., Furlong 2007, Furlong et al. 2017). Attitude surveys have been conducted that capture young people's conceptions about themselves, their future, and the society in which they live (e.g., MUCF 2019; EPSU 2019). Despite the popular image of young people as individualistic and characterized by post-materialistic values, research has shown that most young people primarily want a secure full-time job (e.g., Hult \& Svallfors 2002, Pyöriä et al. 2017, Hirvilammi et al. 2019). However, attitudes and ideas are linked to the conditions at hand. One of the most important changes affecting young adults' lives in so-called 'late modern' society has been that their entry into adult life occurs later. If we go back only a few generations, it is difficult to even talk about a period of youth, much less to apply the term 'young adults'. After basic schooling, most young people simply became adults, whether they wanted to or not. Today, the situation is different. The transition between adolescence and adulthood is extended, and the age of labor market entry and family formation is delayed; both men and women increasingly want to first establish 
themselves on the labor market before starting a family (OECD 2011). In general, entry onto the labor market means the start of a nonlinear process, which in practice involves many temporary jobs under precarious conditions (Kalleberg 2009; Mortimer 2009; Standing 2011). The so-called gig economy boosts the unqualified service jobs that many young people are forced to take, jobs that may entail a performance-based salary and insecure employment conditions. These conditions have severe consequences for many; some young people also periodically refrain from looking for work because of the difficulties that arise (Ylistö 2018). Unemployment as such has a negative impact on young people's health and well-being (e.g., Reneflot \& Evensen 2014). Some studies have also shown that the effects on health are greater for young people who work under precarious conditions (e.g., Vancea \& Utzet 2017).

However, work conditions for the permanently employed are also changing. The new requirements imposed on employees include having not only a relevant educational background, but also a good ability to self-govern and self-regulate (Allvin et al. 2011). Studies have shown that nearly half $(47 \%)$ of the jobs offered on the Swedish labor market are considered low-regulated or unregulated (Allvin et al. 2013); these jobs require that the employee be responsible for structuring, organizing, and executing the work. These changes can be characterized in relation to the notions of individualization (Ebert 2012; Gillberg \& Bergman 2013) or responsibilization (Mounk 2017), which imply that the individual is forced to deal with the boundaries and regulations of the work, tasks that previously rested with the employer or the organization. These new requirements are diffuse and require a self-regulating ability that may be difficult to achieve. Unregulated work based on a self-regulating capacity may give more room for maneuver, but it also increases the pressure on the employee. Furlong and Cartmel (2007) argued that the increasingly individualized labor market (and life in general) has resulted in a shift toward individual responsibility, where various kinds of shortcomings on the labor market fall back onto the individual. Young adults have largely internalized this shift in responsibility:

... Individuals are forced to negotiate a set of risks which impinge on all aspects of their daily life, yet the intensification of individualism means that crises are perceived as individual shortcomings rather than the outcome of processes which are largely outwith the control of individuals. In this context, we have seen that some of the problems faced by young people in modern societies stem from an attempt to negotiate difficulties on an individual level. Blind to the existence of powerful chains of interdependency, young people frequently attempt to resolve collective problems through individual action and hold themselves responsible for their inevitable failure. (Furlong \& Cartmel 2007: p.144)

In light of this background, it is reasonable to argue that young adults are somewhat alone on today's labor market and expected to manage their own employability individually (and expect this of themselves as well). A work life characterized by fragmentation, precarious employment, and high demands on self-governing ability puts pressure on young adults, which may partly explain the increasing mental ill-health found in this part of the population (Canivet et al. 2016; Rönnblad et al. 2019; Tompa et al. 2007).

What, then, is the situation for young adults in the Armed Forces? Although young people's relationship to working life has been relatively well studied, their relationship to the Armed Forces as an organization and employer has received only limited attention. 
In the next paragraph, we briefly describe the research that has been conducted on the relationship between the Armed Forces and young adults, primarily in a Swedish context.

\section{Young adults and the military}

During the past decade, the Swedish Armed Forces have undergone dramatic developments. In 2010, the agency was reorganized in response to perceived positive changes in the international political climate, shifting the focus from national deterrence to international peacekeeping and peacemaking missions. Military units were closed, the compulsory military service system was discontinued, and the organization was downsized. However, Sweden is presently (as of 2020) reinforcing its national defense capacity, increasing military investments, and reintroducing compulsory military service. The recruitment of young people to the Armed Forces has become an important issue, and targeted efforts have been made to persuade young recruits to remain in the Army as permanently employed soldiers or to choose a military career as officers. Arriving at an understanding of the factors influencing young adults to choose a military career is of great importance to the Armed Forces (Strand 2019). The requirements established in the recruitment process are quite tough, the competition for an elite group among young adults on the Swedish labor market is fierce, and youth unemployment is relatively low (e.g., Olofsson \& Wadensjö 2015; Gillberg \& Seldén 2017). The changing mission of the Swedish Armed Forces, the changing nature of warfare, and the need to be part of a societal context are all factors that contribute to organizational restructuring and the introduction of new military management strategies.

Another approach taken in the Nordic research has been a more feminist-oriented constitutive analysis of how a person is to be formed into a soldier (e.g., Sløk-Andersen 2018). Sløk-Andersen argued that becoming 'a good soldier' is a complex process, where the possibility of being recognized as such a person is unevenly distributed in relation to, among other things, gender and various disabilities. Taking a similar perspective, Ellingsen et al. (2016) suggested that the Armed Forces are characterized by masculinity norms that have been compromised with regard to mixed rooms, that is, when soldiers of both sexes live together. In such contexts, both desexualization and a reduction in stereotypical behaviors are noted.

Studying young people's perceptions of the Swedish Armed Forces as an employer, Adolfsson et al. $(2012,2015)$ found that fellowship and coherence contributed to the job satisfaction experienced by soldiers and marines. The relationships that emerge within the Armed Forces create trust (e.g., Eikeland 2015). Österberg and Rydstedt (2018) found that working conditions that offer meaningfulness constituted a key factor underlying job satisfaction. There was also a relationship between complex job content and job satisfaction. Their study indicated that in order to promote organizational commitment in the Armed Forces, it is important to provide working conditions that newly recruited soldiers perceive as meaningful. Similar conclusions have been drawn in international studies (see, e.g., Allen 2003; Gade 2003). Annell et al. $(2018,2019)$ monitored a cohort of newly employed young police officers (a professional category that shares some similarities with military recruits) and investigated the factors causing dropout from the profession after some time of employment. These 
authors concluded that relatively few officers chose to quit; among those who did, a lack of organizational coherence was the most important work-related explanatory factor.

Leadership quality is an important factor related to job satisfaction and experience of meaning and motivation in work. In a study of Swedish soldiers, Brandebo et al. (2019) showed that constructive leadership contributed to experienced meaningfulness and work satisfaction. Österberg (2018) also highlighted individual development, group cohesion, and the opportunity for competence development as key factors in understanding what is required for young people to apply to and stay in the Armed Forces.

Another important facet of the Armed Forces is that military occupations demonstrate low relative risks for sick leave. Indeed, the health statistics in the military are exceptional. Figure 1 shows the relative risks for sick leave in 2013 for all occupations on the Swedish labor market that include more than 10,000 persons. The 'Armed Forces' (occupational code 011 according to Swedish Standard Classification of Occupations, SSYK) show exceptionally low relative risks compared to the labor market as a whole. Given that military personnel may be exposed to extremely

Figure I Relative risk (RR) for sick leave in all diagnoses (horizontal axis) and mental diagnoses (vertical axis) in different occupations (average for all occupations $=1$ ). The data points represent all occupations on the Swedish labor market that include more than 10,000 people. Data source:The Swedish Social Insurance Agency (20 I8).

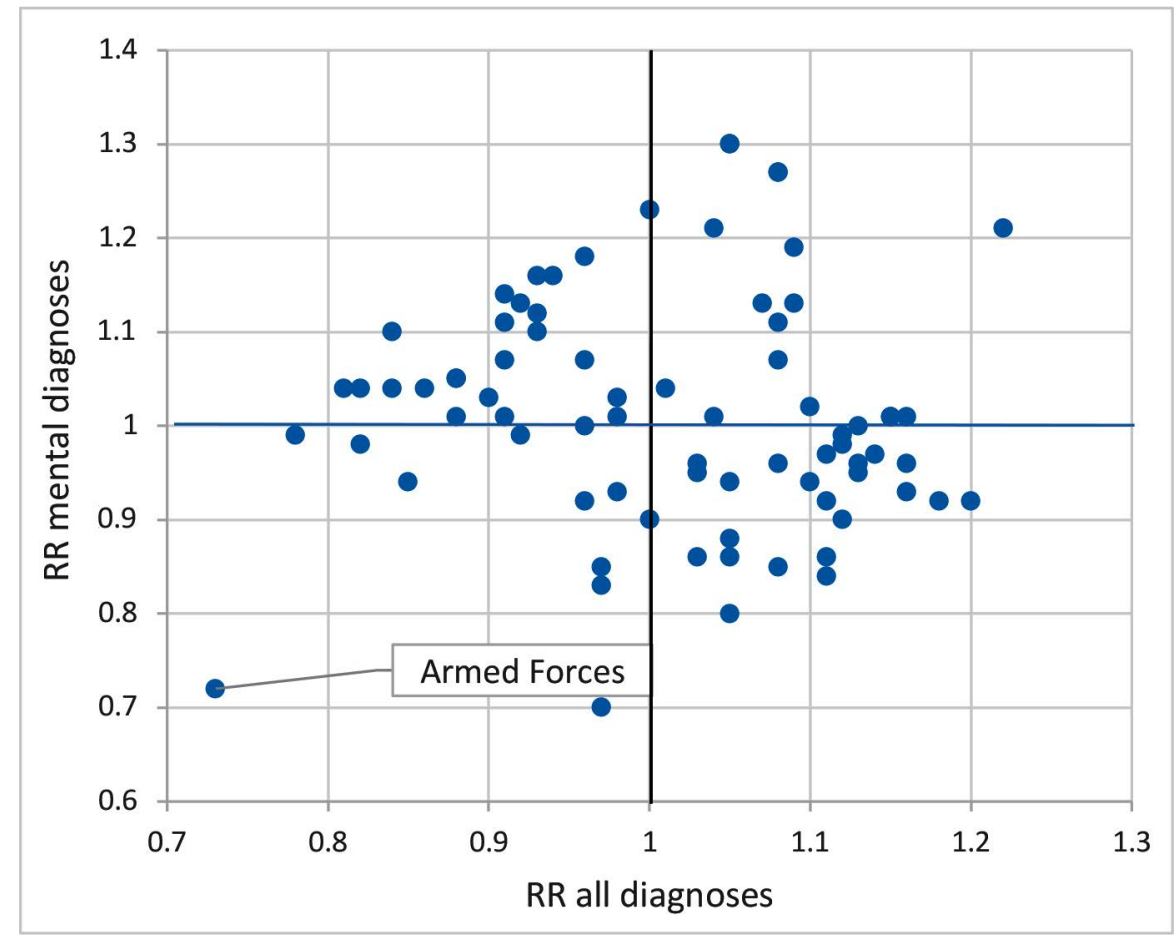


stressful situations, sick leave due to mental diagnoses is of special interest, yet here as well, the Armed Forces are characterized by a very low relative risk $(R R=0.72)$, comparable only to code 612: 'Animal producers and related workers' ( $R R=0.70)$. Sick leave absence among soldiers and marines in particular was a mere $0.7 \%$ for men and $0.5 \%$ for women.

In summary, we can state that young adults' experiences of the Armed Forces are largely positive and that the health rates are positive. This can partly be understood in light of the selective process that precedes employment, where motivation and physical health are tested. In connection with employment, young soldiers are thus already selected, and in connection with basic training, a socialization process begins that influences and shapes the individual soldier. This background should be kept in mind as we approach the interviewed soldiers.

\section{Theoretical framework}

The theoretical foundation of the present study is a critical realistic metatheoretical understanding of the relationship between structure and reflexivity (Archer 1995, 2007). The analytical framework used in the analysis of the interviews can be described as a realistic model (Karlsson \& Bergman 2017; Maxwell 2012; Pawson \& Tilly 1997), the aim of which is to identify the factors and conditions that motivated and influenced the interviewees' perceptions of the Armed Forces. The basic analytical model underpinning the work has been an analytical dualism that distinguishes between structural conditions and agency (Archer 1995; Mutch 2019). This does not mean that these two aspects of life are clearly separated in the everyday world. However, if we are to study the relationship between society and the individual, we must distinguish between the actions of agents (i.e., the actions and intentions of individuals and groups) and the structures (that either enable or constrain these groups' and individuals' actions in the world). Both agents and structures produce generative mechanisms, meaning that they make things happen in the world (Sayer 1992: 104-109), the critical difference being that structures are devoid of intentionality. Structures exist and condition the actions that take place. This provides a perspective the views young adults' conditions and opportunities on the labor market as an interaction between the conditions that prevail and their reflexive capacity. In this context, one can talk about both internal and external conditions that limit and enable an individual's potential. This does not mean that the individual is determined by these conditions; rather, the relationship between the individual's reflexivity and the internal and external structural conditions is interesting, if our goal is to identify and understand the mechanisms that influence young adults and cause them to adopt a strategy and make decisions about their future. One way to approach this gap between structural conditions and agency is through interviews that highlight the internal conversation that always takes place when the individual's resources meet the structural conditions of the surrounding context (Archer 2007).

The sense of coherence (SOC) experienced by military recruits seems to contribute to a positive view of the organization and may predict whether they will remain in the military (Larsson \& Melin 2015). A SOC is strongly related to perceived health, especially mental health, but less so to physical health (Eriksson \& Lindström 2006). According to Antonovsky $(1979,1996)$, workplaces in which employees experience a

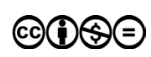


high SOC may be characterized as salutogenic (health promoting): the stronger the SOC, the better the perceived health. As shown in Figure 1, in the military both general and mental health are exceptional. These considerations make it relevant to document the occurrence of the elements of SOC in the interviews: comprehensibility, manageability, and meaningfulness. It may be hypothesized that military working life provides a high SOC, and thereby possesses salutogenic qualities.

To understand the rationales behind these young recruits' decisions to apply to and remain in the army, the present study poses two key questions: What is the importance of the individual's resources? How important is the institutional context young recruits experience?

\section{Contextual conditions}

\section{Recruitment processes}

In 2016, the Swedish Armed Forces identified a need to recruit 3000 young people age 18 years and above to military basic training (MBT) annually. ${ }^{i}$ After completion of a training period of $6-8$ months, the recruits could choose employment as a soldier or marine, or to study to become an officer. The MBT selection process is quite rigorous. The Swedish Army holds that recruitment to the military must be based on strict criteria, aiming to match individual capability with the needs of the organization. Figure 2 shows the steps in the recruitment of soldiers and marines to MBT, and how the selection process was applied to those who finished their training in 2013 (SOU 2016). Invitations were sent to all youngsters at the age of 18 . In the first step, a set of formal criteria were applied (citizenship, age, educational background) to all applicants. The second and third steps comprised checks for health status, personal interests, attitudes toward military service, and security. The final in-house testing included physical and psychological performance (Bäccman 2015). At the end, those approved for MBT by the Defense Recruitment Agency were subject to individual assessment by a selection panel, where the Swedish Army Human Resource Centre reviewed the applicants and made a final decision, also taking into account the needs of the organization (Swedish Armed Forces 2012). Among the original applicants, $20 \%$ were women. The proportion of women in the group actually completing the MBT decreased to $14 \%$.

A small proportion of those who started their MBT did not complete the training period (approximately 16-20\% in 2013-2016). The main reasons for not finishing the MBT included health concerns, injuries, psychological or social problems, and security considerations. There were comparatively few voluntary dropouts; among them, reasons included social concerns or transferring to other studies (Swedish Armed Forces 2020). Those who have passed the selection process, achieving approval by the Defense Recruitment Agency and final acceptance by the Human Resource Centre represent a small fraction of those who applied to the MBT originally. These young adults may be characterized as a physical and mental elite, in their own view as well. This may also hold in an international perspective. A senior officer with experience of working with other countries in peacekeeping operations declared that Swedish soldiers were much more able than most soldiers from other countries: 'I think that we have been successful in our marketing of the occupation as a soldier or marine higher up in the supply of 
Figure 2 The stepwise recruitment process applied by the Swedish Army (SOU 2016).

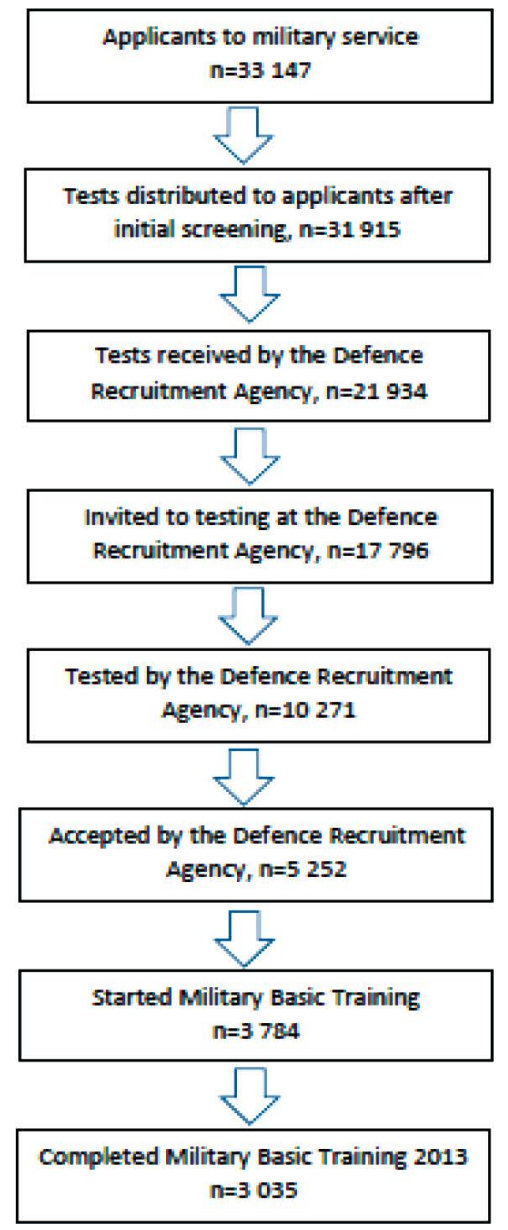

youngsters. It's really something where you need to be talented, more than in many other occupations' (Gillberg et al. 2018).

Out of those who completed MBT, around $80 \%$ subsequently decided to join the military in some role. Approximately one-third became soldiers or marines, contracted for 6-8 years (Swedish Armed Forces 2017). This is the group in focus in the present study.

\section{The organizational context}

The Armed Forces may be characterized as a combination of a mechanistic and a professional organization, where the profession creates identity and safety and where the hierarchical, mechanistic structure guarantees stability and a clear specialized differentiation 
between functional assignments (Kadefors \& Blomsterberg 2011). The Armed Forces may also be described as an organization characterized by specific norms and values formed within the framework of the historically conditioned task of defending the country. A hierarchical command structure, an altruistic task of defending the country, and an emphasis on cohesion and community in everyday work are the contextual conditions that characterize the work. This normative basic premise can also be described in relation to an institutional logic (see, e.g., Mutch 2018; Thornton 2012) that emphasizes tradition, hierarchies, and altruistic goals. Thornton et al. (2012) argued that institutional logics permeate the organizational and professional conditions that enable certain approaches and activities and complicate others. The institutional logic becomes an important part of both the organization and the individual's identity, defining the values that apply and the decision-making processes that are acceptable. The way in which the Armed Forces relates to change and implementation of change processes can also be seen as an expression of the institutional and professional logic that characterize the Armed Forces, where a clear command structure forms the basis for the organization and the profession. The organizational conditions surrounding the employed soldiers are largely characterized by this institutional logic, which constitutes the framework within which the soldiers are trained and educated.

\section{Method and material}

The present approach was partly inductive, but was developed via an abductive process into a study that alternated between empirical findings and theoretical concepts (e.g., Layder 2013). A qualitative approach was chosen aimed at capturing the young soldiers' and marines' own experiences of working in the Armed Forces. The interviews were semi-structured, recorded, and transcribed. Each interview lasted for about 1 hour. A number of biographical data points were obtained initially, such as parents' occupations and education, previous studies, and work experience. The interviewees' anonymity was ensured. The semi-structured approach mainly involved three overall thematic areas, addressed by asking the following questions: (1) Why did you apply for the Armed Forces, (2) How do you perceive your current employment and workplace? (3) Are you going to stay in the Armed Forces? The last thematic area (3) includes, in most cases, follow-up questions regarding the main reasons why the interviewee sees a future in the Armed Forces as well as what could cause him or her to leave the position.

\section{The interviewed soldiers and marines}

The empirical data were derived from interviews with 37 newly contracted soldiers and marines: 29 men and eight women. They had all completed 6 months of MBT before signing a time-limited contract of 8 years. The interviews were conducted at units representing different branches of the Armed Forces (army, navy, air force). The study comprised recruits who had enlisted with the Armed Forces before mandatory conscription was reintroduced in 2019. The interviewed soldiers were offered to participate, but participation was voluntary and the selection can be described in terms of a self-selection. 
The interviewees were drawn from two different groups. The first group of 17 people was interviewed in 2017. They had all undergone a life and career planning course under the auspices of the Armed Forces. They represented the different branches of the Armed Forces (army, air force and navy). The selection contained five women and 12 men; the median age was 26 years, and their median time as employees in the Armed Forces was 6 years.

The second group was a cohort of 20 soldiers and marines, interviewed on two occasions, in 2018 and 2019. The cohort contained four women and 16 men. The Armed Forces invited new recruits to participate in the interviews at selected units, representing a diversity with respect to geographic location and branch (army, air force, and navy). Participation was voluntary. At the first interview, the interviewees had been employed for about one year; the median age was 22 years. This study was therefore based on a total of 57 interviews with 37 individuals.

All interviewees in the cohort had completed upper secondary education. One of the interviewees had an undergraduate academic degree. Three of the interviewees had parents with a military background. A majority of those interviewed came from relatively common socio-economic circumstances: 16 of the interviewees in the cohort had parents who belonged to what could be characterized as middle-class or professionally trained working class. One of the interviewees had a parent who worked in the Armed Forces; another one had parents who worked as academics at a university.

\section{Processing and analysis of the interviews}

The analysis of the material was carried out in three steps. In the first step, a content analysis of the interview material was conducted, giving rise to some general categories (see, e.g., Ryan \& Bernard 2003; Braun \& Clarke 2006; Fereday \& Muir-Cochrane 2006). These general categories were then analyzed in more detail using groundedtheory-inspired coding, where the primary codes gradually evolved to more comprehensive and theoretically useful codes, with a view to capturing the central aspects of the interviewees' motives and perceptions.

The next step in the analysis was to relate these categories to the structural conditions (i.e., to the institutional and organizational prerequisites) that characterize the Armed Forces as an employer. Theoretical perspectives have also been adjusted during the analysis (e.g., Antonovsky's concept Sense of Coherence), which in practice has led to an interaction between the empirical and the theoretical (see Layder 1998: 37-42).

The final step involved a so-called retroductive process, in which we conceptualized the mechanisms that affected the interviewed soldiers and marines in different directions. Retroduction can be described as a thought operation that reconstructs the basic conditions for something to be what it is, or in other words, arguing for the properties that must exist for a phenomenon to be possible (Danermark et al. 2019; Gillberg, 2017).

\section{Results and analysis}

The analysis led to three generative mechanisms that played crucial roles for the young soldiers and marines with respect to deciding to apply to and remain in the Armed Forces: (a) meaningfulness, (b) fellowship, and (c) structure and safety. 


\section{Meaningfulness}

One issue characterizing the interviews was capture in the question: Why do young people apply to the Armed Forces? The answers to this question varied, but one common denominator was that the Armed Forces stand for something different and exciting. One of the soldiers described this as follows:

... it was exciting. A little different maybe. Everyone in high school doesn't join the military ... so. (soldier/man)

The interviews showed that there are a number of components linked to the specific institutional logics of the Armed Forces that attract young adults to both seek and stay in the profession. Meaningfulness and stability were among the key concepts that emerged during the analysis.

... you know you're doing something for Sweden as well as ... for the country ... defending the population. That was one of the reasons [for me to join]. Other reasons were that it really interested me a lot. Being challenged and being able to do things outside your comfort zone. And that's been tested now ... both physically and mentally. Those are the reasons why you're here and why you want to stay. (soldier/woman)

Making an effort for the country while also challenging oneself was a key motivator for many of the interviewees. The need for a collective and shared mission was thought to give the interviewees a sense of meaning in life.

So why do not more young adults apply to the Armed Forces if a need for meaning and collective community is what is required? One of the interviewees highlighted the following:

I think ... most people are aiming for a career with a lot of money ... that's what I think. I come from a technology program and many people are looking to become engineers and similar things and I think money will be a big issue. They opt out ... what I consider to be a fun and rewarding profession ... for other jobs where they get paid more. I think the money issue is important. (soldier/man)

Another young soldier said:

... if you look at my friends, I think they're a little too comfortable. Most of my friends went to some vocational high school ... maybe construction or something ... and yes ... it might be comfortable there and they might think it sounds awful when you talk about GMU (military basic education) and things ... (soldier/man)

One of the young female soldiers raised the question of why some young women are abandoning the Armed Forces:

I think it's because you think you have to be so good physically ... that you have to be so fast and strong and so on. I thought so myself, like ... that I will not catch up with their 
pace ... I think so. But I wouldn't say that is the hardest thing. But you have to be stubborn and really want to be here. I noticed it on an exercise we were on ... that when you didn't get enough food and sleep ... then there were several guys ... those who were the biggest and strongest ... who started to slow down a bit. That's exactly where the stubbornness comes in ... (soldier/woman)

From a soldier's perspective, the reason why so few apply to the Armed Forces is primarily considered an economic issue. However, as most of the interviewees pointed out, it is not for the sake of money one chooses to stay in the Armed Forces. Convenience and a fear of hard physical training are also aspects highlighted to explain why young adults do not choose the Armed Forces. Meaningfulness, as a generative mechanism, is of great importance to deciding to continue employment in the Armed Forces. Defending the country and being part of something that goes beyond the primary drive to make money are factors that greatly influence young people's decision to continue their military careers.

\section{Fellowship}

What characterizes the Armed Forces as a workplace and organization, and what is considered the best part of being a soldier or marine? The answers were similar to the reasons given for why the Armed Forces were chosen as an employer, but also appreciation of the fellowship and identity that had emerged in relation to the work and the tasks. Several interviewees highlighted the fellowship and the relatively clear tasks they shared with their superiors:

... I've always liked the 'green clothing' and I think it's great ... I mean the way we work together ... it's a great friendship ... and that you live so close together. (soldier/man)

... how should I put it? ... hmm ... just this community ... that you feel like you always have someone to be with and talk to ... well I like that anyway. (soldier/woman)

You get very close to the people you work with and ... you get a whole new family ... to be with ... that you can rely on all the time. (marine/man)

Another aspect many interviewees stressed was the challenges they faced and the personal development that contact with the military had meant for them.

You grow as a person ... and you learn so much about yourself and you constantly get new experiences. I think it's very good for maturity ... You become so mature and you get to know yourself ... you feel that you can handle things and you realize you can do more than you thought initially. You get to know your weaknesses and strengths and I think it's very good to get to know about yourself as well. How to deal with stress and so on. (soldier/woman)

The fellowship emerged is a central generative mechanism that derives from the Armed Forces' emphasis on the vital importance of the group to the work done in the military. 
In other words, the fellowship makes things happen; it plays a crucial role in the decision to invest in a military career.

\section{Stability and structure}

In what way does the Armed Forces differ from other employers? An important aspect is the stable structure and security the military is thought to represent. Although the Armed Forces are sometimes considered a slow and bureaucratic organization, the soldiers also perceived this as an expression of stability and security. If other areas of working life are considered fragmentary and stressful, the Armed Forces are seen as the opposite. The clear and hierarchical structure that characterizes the organization was largely perceived as something positive. Two soldiers described it as follows:

... I haven't tested any civil work, but many of my friends who switched to a civilian career have said that ... 'I have to go back' ... it may have to do with that structure ... in the workplace here ... that we have order and rank system and so on ... (soldier/ woman)

It's nice to be able to talk to my immediate superior about everything, but at the same time he's the one who decides. If he says something then you do it ... I have no problem with that. It's a good structure that works well. (soldier/man)

... the Armed Forces will always remain and ... just that it's a government agency ... and you know ... rules and procedures that support us ... and of course we won't go bankrupt, and we've been around forever and will probably be in the future as well. Sometimes you think it's nice and safe and you know you have a job to go to. (soldier/ man)

Thus, the last generative mechanism that causes young people to want to stay in the Armed Forces is the stability and structure that the work entails. Clear decision paths, a clear managerial role and, above all, long-term stability that does not involve reorganization and unemployment are aspects that characterize this mechanism. It also largely ties in with the picture that was initially drawn about the increasingly uncertain civilian labor market.

\section{Why apply to and stay in the army? Mechanisms and individual effects}

Meaningfulness, Fellowship and Stability (in relation to a well-structured organization) are, as we have seen, three main concepts related to the central questions concerning why a young adult would decide to stay in the military. Moreover, they can be considered important generative mechanisms.

For most interviewees, applying to the Armed Forces was a well-considered decision. Some said they had applied because they wanted to try something different, but 
that the final decision had been made after examining the conditions thoroughly. For many, military service constituted a natural part of reaching adulthood. A few interviewees had parents or relatives working in the military, but most had no one in their surroundings with such a background. The female interviewees emphasized that applying to the military was a different and exciting decision; it was a way for them to do something special, a personal choice based on curiosity and interest.

The interviews showed that the newly contracted soldiers and sailors quickly developed a SOC and identification. Wearing a uniform and completing tasks together with comrades created a feeling among most people that they fit into a larger context. Several interviewees felt this was a basic difference compared to previous work experience. Friendship and common identity quickly became an important motivating factor and were also largely cited as reasons for staying in the Armed Forces.

Perhaps the most prominent experience that emerged through the interviews was the feeling of structural stability and thereby security. Although the bureaucratic and hierarchical organization was sometimes perceived as slow, the leadership, the clear and well-thought-out command structure and proximity to the commander all represented security. Many interviewees described this as always having the opportunity to get immediate help from one's supervisor - the nearest officer - if things went wrong. They described the satisfaction that came from learning their tasks and being constantly supported during training. Everyone had some experience of working life; one difference that was emphasized was the good leadership in the Armed Forces.

The picture that emerges regarding the Armed Forces is apparently very positive. Working and training are considered meaningful and provide social identity, structure, and stability. The Armed Forces seem to offer something radically different from the labor market in general, which is characterized by a high degree of individualized responsibility, insecure employment, and few opportunities to learn at work. The reasons why some young contracted employees leave the Armed Forces were mostly explained as a matter of personal economy. Wages are low and wage growth during a military career is slow compared to the situation on the civilian labor market. Young adults who want to start a family and perhaps buy a home may have to jump to a civilian job. However, many interviewees are prepared to accept a lower salary, given the other benefits of work in the Armed Forces. One common remark made by the interviewees is that you do not work in the military for the money, but because the job is interesting and meaningful. Examples of the practical and more concrete benefits highlighted include the opportunity to go to the gym during working hours, the long periods of compensatory leave that can be utilized on a regular basis, and the easily accessible healthcare system.

The study partly confirms the conclusions made in previous studies on soldiers and marines in the Armed Forces (e.g., Österberg \& Rydstedt 2018), showing that cohesion, meaningful work and development opportunities are important explanatory mechanisms underlying the soldiers' positive image of the Armed Forces. In line with Annell et al. (2019), we note that one important work-related explanatory factor is a sense of organizational coherence. The military and the role as a soldier or marine became an important identity marker. The interviews indicated that what was perceived as a meaningful mission, a safe job, and a clear organizational context played a role in the development of emotional and identity-enhancing bonds to the organization and work tasks. Another aspect of the same theme concerns the leadership. Overall, the leadership 
was perceived as very good and supportive. One of the interviewees who had left the Armed Forces (for salary reasons) described the difference as follows:

... the managers you have at XX [his current employer], they work during the day and they have their job no matter what. The officers in the Armed Forces were much more involved in the everyday work and took part in exercises and so on. It's an incredible difference ... you don't have the same contact with the heads now as when you were in the Armed Forces ...

This interview also highlighted salary as the most important explanatory factor for why soldiers leave or contemplate leaving the Armed Forces and applying for a civilian profession. This discussion is held both with colleagues and with managers in the organization. The term 'civilian darkness', which refers to society outside the military community, has been used extensively in this discussion. The concept highlights the ambivalence that many express when talking about the future and various possible career choices. Staying within the Armed Forces is something most of the interviewees wanted, but they were all aware that this choice can have financial consequences. The Armed Forces symbolize security, stability, and meaningful work, but salary remains a big issue. Figure 3 summarizes the main conclusions and highlights the generative mechanisms identified through the analysis of the interviews.

Figure 3 Generative mechanisms and individual effects regarding the soldiers' and marines' relation to the Armed Forces.

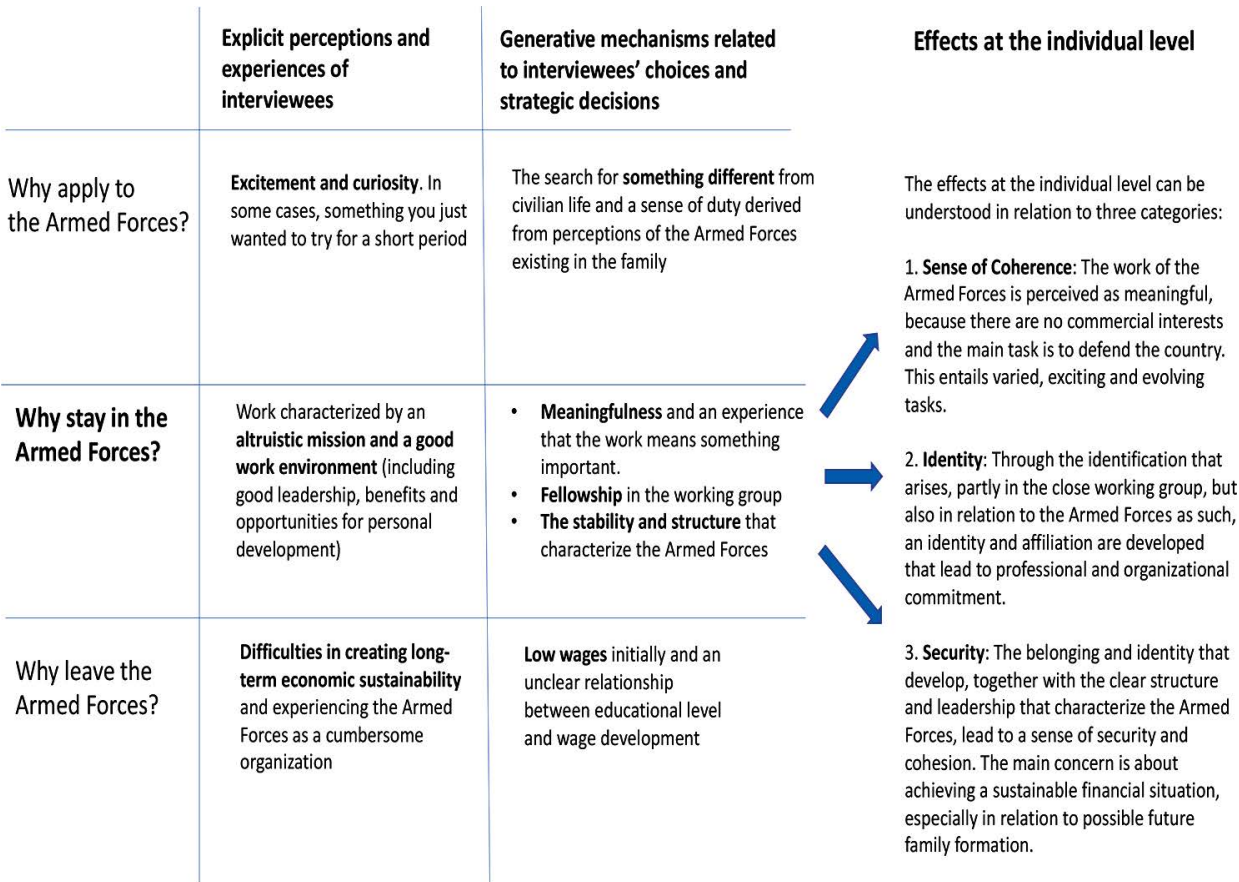




\section{Theoretical implications}

\section{Contextual conditions and agency}

The basic analytical distinction between structural conditions and reflexive considerations the present article is oriented toward can be described, in more concrete terms, as an analysis of the contextual conditions and generative mechanisms that derive from the institutional and organizational logic of the Armed Forces. The traditional hierarchical command structure, the altruistic task of defending the country and the emphasis on cohesion and community in everyday work are the contextual conditions that characterize the work. The organizational and institutional conditions make things happen, that is, they produce generative mechanisms that shape the young soldiers' reflexivity. However, the relationship between reflexivity and structural conditions does not have a one-way influence, such that the specific conditions of the Armed Forces are instilled in the soldiers. The specific conditions and institutional logic that characterize the Armed Forces also meet the needs that have emerged through the reflexive considerations the young soldiers have made in relation to a civilian labor market that, in some cases, is perceived as fragmented and insecure.

Research has indicated that the conditions and circumstances that shape (make) the soldier's self-image are a combat-oriented ideal of masculinity and that adaptation to this is necessary if one intends to make a career in the Armed Forces (e.g., Ellingsen et al. 2016; Sløk-Andersen 2018) However, we would argue that the soldiers' experience of the Armed Forces contains a complex composition of aspects that derive in part from an institutional logic that emphasizes tradition, hierarchies and altruistic goals, but that is also the result of the young soldiers' conscious reflexive considerations, where they prefer security and stability to the uncertainty that prevails on the civilian labor market. Many are thus prepared to sacrifice parts of their independence and scope of action in exchange for a safe and meaningful job.

\section{The Armed Forces as a salutogenic organization}

As we initially described in the present article, according to the Swedish Armed Forces (2012), the health situation in the Armed Forces is extremely good; sick leave absence among soldiers and marines in particular was a mere $0.7 \%$ for men and $0.5 \%$ for women. According to sick leave statistics presented for all governmental agencies (The Swedish Agency for Public Management 2016), the Armed Forces have the lowest rating, $2.0 \%$; this number includes non-military employees, who constitute about $25 \%$ of the total. However, the rate of sick leave among civilian employees, $3.5 \%$, does not differ from that of other governmental agencies. In other words, the low absence due to sickness among military employees may be primarily attributable to factors other than the quality of the Armed Forces as an employer. The Armed Forces (2020) declared themselves that 'the relatively low rate of sickness leave is attributed to good working conditions, access to physical training during work hours, high presence of and high trust in the supervisor, and the results of the selection process'. Life as a soldier or marine may therefore be characterized as salutogenic (health-promoting), that is, as helping people overcome hardships and 
extreme stress (e.g., Antonovsky 1996). Here, the SOC is particularly important. In the present study, we found that many interviewees showed signs of experiencing a high SOC.

\section{The Armed Forces and the surrounding society}

The structural and institutional conditions that cause young people to stay in the military can be described in relation to tradition, stability, and clarity. In other words, the Armed Forces stand for something completely different: a structure and logic that differs from other activities in society. For many young adults, this option is attractive and, in some cases, liberating. The interviewed young people developed a high degree of emotional attachment and affective commitment to the organization relatively quickly. From a societal perspective, therefore, it can be argued that the Armed Forces and the institutional logic that characterizes this organization provide dimensions in life that many young people lack: structure, clarity, and cohesion.

Therefore, the present study may be relevant from a broader perspective by giving rise to the following question: How do young adults relate to the conditions offered in different sectors of the labor market? More or less populist perspectives highlight the changing view of work and work ethics that characterize the generations born in the 1980 s and 1990s. There is a general view of a spoiled, selfish and project-oriented generation. However, there is relatively strong support for the argument that young adults are instead asking for meaningful and fulfilling work. For instance, Okay-Somerville et al. (2019) emphasized that career development and sense of meaning are important indicators of whether young people feel satisfied in the workplace; in other words, meaningfulness provides an explanatory mechanism if we want to understand the relationship that develops between the individual and a particular workplace or profession. In the present study, we argue that the Armed Forces offer an alternative that generates what is often lacking on the civilian labor market. Therefore, the internal conversation the young soldiers and marines are having can be described as a negotiation between the structural conditions that characterize the Armed Forces as an organization, the internalized resources the young people have at their disposal, and the possible opportunities offered on the civilian labor market. This means that the negotiations the young people conducted when they decided to stay in the Armed Forces are based on conscious reflexive considerations that involve a perception of the civilian labor market as unsatisfactory.

\section{Conclusions}

In the present article, we have argued that the Armed Forces offer a work environment that is salutogenic in a number of ways. We can conclude that, for most of the interviewees, joining the military was a conscious choice. What was perceived as a meaningful mission, a safe job, and a clear organizational context played a role in strengthening the emotional and identity-enhancing bonds that developed in relation to the organization and the task. In light of the interviews conducted, we have concluded that, within the framework of the Armed Forces' organizational and institutional logic, there are generative mechanisms that respond to the relatively basic needs of the young people who have 
recently been hired. Of course, it is not possible to ignore the selection process that takes place when those who are later employed as soldiers undergo their basic training. The very fact of having been admitted to the undergraduate education presupposes both that the individual is healthy and relatively motivated. The selection then continues such that the most motivated and interested are offered employment. The group that is eventually employed is thus not comparable to the youth population in general. This may to some extent explain the positive image of the Armed Forces that emerges in the interviews, but it cannot fully explain the emerging experience of community and meaningfulness. The present analysis suggests rather that the desire to remain employed as a soldier or marine in the Swedish Army is based on a combination of individual and organizational factors. The selection process is one of them, but the sense of meaningfulness and organizational coherence are at least as important.

Reducing the explanation to a successful selection process, however, underestimates the salutogenic aspects. We should instead try to understand what happens when we use a multifactorial explanatory model that includes both selection processes and salutogenic organizational conditions. We therefore wish to argue that a number of generative mechanisms linked to the contextual conditions offered by the Armed Forces are relevant to take into consideration if we are to understand the processes that create this organizational coherence among soldiers and marines.

\section{Further research}

Note that most of the interviewees were rather recently employed at the time of the interviews and, thus, had only limited experience of the Armed Forces as an employer. In this connection, some pertinent questions are: To what extent do the immediately positive views of the military sustain over time? How will the development of individual and work-related push and pull factors, and the organizational commitment of newly employed soldiers and marines, affect their decisions to stay or to leave in the long run? Longitudinal studies are needed if we are to address these questions, and the results of such studies are likely to be of interest not only to the personnel management of the Armed Forces, but also to other employers and agencies dealing with recruitment of young adults and their socializing into working life.

\section{References}

Adolfsson, P., A. Diedrich, F. Lavén, and L. Walter (2012). I förändringens tid vardagsberättelser från Försvarsmakten. [In the era of change - everyday stories from the Armed Forces]. Gothenburg Research Institute, School of Business, Economics and Law, University of Gothenburg. http://hdl.handle.net/2077/31788.

Adolfsson, P., A. Diedrich, N. Gillberg, F. Lavén and L. Walter (2015). Personalförsörjning och validering inom Försvarsmakten [Personnel supply and validation within the Armed Forces]. Gothenburg Research Institute, School of Business, Economics and Law, University of Gothenburg. http://hdl.handle.net/2077/38273.

Allen, N. J. (2003). Organizational commitment in the military: a discussion of theory and practice, Military Psychology 15(3): 237-253. doi: https://doi.org/10.1207/ S15327876MP1503 06. 
Allvin, M., G. Aronsson, T. Hagstrom, G. Johansson and U. Lundberg (2011). Work without Boundaries: Psychological Perspectives on the New Working Life, Oxford: WileyBlackwell. doi: https://doi.org/10.1002/9781119991236.

Allvin, M., C. Mellner, F. Movitz and G. Aronsson (2013). The diffusion of flexibility: estimating the incidence of low-regulated working conditions, Nordic Journal of Working Life Studies 3(3): 99-116. doi: https://doi.org/10.19154/njwls.v3i3.3013.

Annell, S., P. Lindfors, G. Kecklund and S. Sverke (2018). Sustainable recruitment: individual characteristics and psychosocial working conditions among Swedish police officers, Nordic Journal of Working Life Studies 8(4): 3-24. doi: https://doi.org/10.18291/njwls.v8i4.111926.

Annell, S., M. Sverke, P. Gustavsson and P. Lindfors (2019). Lämna yrket eller stanna kvar? En studie om nya poliser. [Leaving the occupation or remaining?] Arbetsmarknad \& Arbetsliv 25(2): 6-27. http://urn.kb.se/resolve? urn=urn:nbn:se:kau:diva-7484.

Antonovsky, A. (1979). Health, Stress and Coping, San Francisco: Jossey-Bass.

Antonovsky, A. (1996). The salutogenic model as a theory to guide health promotion, Health Promotion International 11(1): 11-18. https://academic-oup-com.ezproxy.ub.gu.se/ heapro/article/11/1/11/582748.

Archer, M. S. (1995). Realist Social Theory: The Morphogenetic Approach, Cambridge: Cambridge University Press. doi: https://doi.org/10.1017/CBO9780511557675.

Archer, M. S. (2007). Making our Way through the World: Human Reflexivity and Social Mobility, Cambridge: Cambridge University Press.

Bäccman, C. (2015). Non-cognitive Assessments for the Selection of the Swedish Voluntary Soldier of Peace. PhD Thesis. Karlstad University Studies 2015: 46. http://kau.diva-portal.org/smash/get/diva2:853442/FULLTEXT01.pdf.

Brandebo, F. M., J. Österberg and A. K. Berglund (2019). The impact of constructive and destructive leadership on soldier's job satisfaction, Psychological Reports 122(3): 10681086. doi: https://doi.org/10.1177/0033294118771542.

Braun, V. and V. Clarke (2006). Using thematic analysis in psychology, Qualitative Research in Psychology 3(2): 77-101. doi: https://doi.org/10.1191/1478088706qp063oa.

Canivet, C., T. Bodin, M. Emmelin, S. Toivanen, M. Moghaddassi and P.-O. Östergren (2016). Precarious employment is a risk factor for poor mental health in young individuals in Sweden: a cohort study with multiple follow-ups, BMC Public Health, 16(1), [687]. doi: https://doi.org/10.1186/s12889-016-3358-5.

Danermark, B., M. Ekström, and J. C. Karlsson (2019). Explaining Society: Critical Realism in the Social Sciences (2nd ed.), Abingdon: Routledge.

Ebert, N. (2012). Individualisation at Work: The Self between Freedom and Social Pathologies. Ashgate Publishing Group. doi: https://doi.org/10.4324/9781315588407.

Eikeland, T. (2015). Emergent trust and work life relationships: how to approach the relational moment of trust, Nordic Journal of Working Life Studies 5(3): 59-77. doi: https:// doi.org/10.19154/njwls.v5i3.4807.

Ellingsen, D., U.-B. Lilleaas and M. Kimmel (2016). Something is working-but why? Mixed rooms in the Norwegian army, NORA - Nordic Journal of Feminist and Gender Research 24(3): 151-164, doi: https://doi.org/10.1080/08038740.2016.1236037.

EPSU (2019). Young Workers: Attitudes to Work Society, Brussels: European Federation of Public Service Unions. doi: https://www.epsu.org/sites/default/files/article/files/EN Young \%20workers.pdf.

Eriksson, M. and B. Lindström (2006). Antonovsky's sense of coherence scale and the relation with health: a systematic review, Journal of Epidemiology \& Community Health 60(5): 376-381. doi: https://doi.org/10.1136/jech.2005.041616.

Fereday, J. and E. Muir-Cochrane (2006). Demonstrating rigor using thematic analysis: a hybrid approach of inductive and deductive coding and theme development, International Journal of Qualitative Methods 5(1): 80-92. doi: https://doi.org/10.1177/160940690600500107. 
Furlong, A. and F. Cartmel (2007). Young People and Social Change: New Perspectives. (2. ed.), Buckingham: Open University Press.

Furlong, A., J. Goodwin and S. Hadfield (2017). Young People in The Labour Market: Past, Present, Future. Abingdon, Oxon: Routledge.

Gade, P. A. (2003). Organizational commitment in the military: an overview, Military Psychology 15(3): 163-166. doi: https://doi.org/10.1207/S15327876MP1503 01.

Gillberg, G. and A. Bergman (2013). Individualisation in working life: work and reflexive patterns among young adults in Sweden, International Social Science Journal 64: 213-214, 225-236. doi: https://doi.org/10.1111/issj.12051.

Gillberg, G (2017). Kritisk realism i praktiken [Critical realism in practice], In: Gillberg, G., S. Persson, D. Selden and U. B. Wennerström (eds.) Social struktur och mänskligt handlande [Social structure and human action]. Malmö: Gleerups.

Gillberg, G. and D. Seldén (2017). Ålder och arbete [Age and work]. In: Bengtsson, M. and T. Berglund (eds.), Arbetslivet. Lund: Studentlitteratur.

Gillberg, G., J. Holmer, R. Kadefors and A. Östebo (2019). Institutionella logiker och målkonflikter vid införande av nya riktlinjer för personalutveckling [Institutional logics and target conflicts when introducing new guidelines for staff development], Arbetsmarknad \& Arbetsliv (1-4):220-237. urn:nbn:se:kau:diva-75433.

Gillberg, G., J. Holmer, R. Kadefors and A. Östebo (2018). Interview data file, Department of Sociology and Work Science, University of Gothenburg.

Hirvilammi, T., M. Väyrynen, I. Stamm, A.-L. Matthies and K. Närhi (2019). Reflecting on work values with young unemployed adults in Finland, Nordic Journal of Working Life Studies 9(2): 87-104. doi: https://doi.org/10.18291/njwls.v9i2.114802.

Hult, C. and S. Svallfors (2002). Production regimes and work orientations: a comparison of six western countries, European Sociological Review 18(3): 315-331. doi: https://doi. org/10.1093/esr/18.3.315.

Kadefors, R. and M. Blomsterberg (2011). A Swedish programme for phasing out older employees based on consent and social responsibility. In: Working and Ageing. Guidance and Councelling for Mature Learners. European Centre for the Development of Vocational Training (Cedefop), Luxembourg: Publications Office of the European Union, pp. 244-260. http://www.cedefop.europa.eu/EN/Files/3062 en.pdf.

Kalleberg, A. L. (2009). Precarious work, insecure workers: employment relations in transition, American Sociological Review 74(1): 1-22. doi: https://doi.org/10.1177/0003122 40907400101.

Karlsson, J. Ch. and A. Bergman (2017). Methods for Social Theory: Analytical Tools for Theorizing and Writing, Abingdon, Oxon: Routledge. doi: https://doi.org/10.4324/ 9781315595115.

Larsson, A. and J. Melin (2015). Personlighet och känsla av sammanhang som prediktorer för avhopp från grundläggande militär utbildning. [Personality and sense of coherence as predictors of turnover from the Swedish military education program]. Thesis, University of Örebro. [In Swedish, with an English abstract]. doi: https://www.diva-portal.org/ smash/get/diva2:909458/fulltext01.pdf.

Layder, D. (1998). Sociological Practice: Linking Theory and Social Research, London: SAGE.

Layder, D. (2013). Doing Excellent Small-Scale Research (1st ed.), Thousand Oaks: SAGE Publications. doi: https://dx.doi.org/10.4135/9781473913936.

Maxwell, J. A. (2012). A Realist Approach for Qualitative Research, Thousand Oaks: SAGE Publications.

Mortimer, J. T. (2009). Changing experience of work. In: Furlong, A. (ed.) Routledge Handbook of Youth and Young Adulthood, Abingdon Oxon: Routledge, pp. 149-156.

Mounk, Y. (2017). The Age of Responsibility: Luck, Choice, and the Welfare State, Cambridge, Massachusetts: Harvard University Press. 
MUCF (2019). Unga med attityd. Attityd- och värderingsstudie [Youth with an Attitude. A Study of Attitudes and Values]. Växjö: The Swedish Agency for Youth and Civil Society. https://www.mucf.se/publikationer/unga-med-attityd-2019-del-2.

Mutch, A (2018). Reframing Institutional Logics, New York: Routledge.

Mutch, A. (2019). Margaret Archer and a morphogenetic take on strategy, Critical Perspectives on Accounting. doi: https://doi.org/10.1016/j.cpa.2016.06.007.

OECD (2011). Doing better for families. In: Families are Changing, Paris: OECD. https:// www.oecd.org/els/soc/47701118.pdf.

Okay-Somerville, B., D. Scholarios and E. Sosu (2019). Young workers' job satisfaction in Europe, In: Furåker, B. and K. Håkansson (eds.) Work Orientations: Theoretical Perspectives and Empirical Findings, New York, NY: Routledge. doi: https://doi. org/10.4324/9781351121149.

Olafsdottir, S. (2019). Mental health: Current trends and challenges in the Nordic countries and beyond, Scandinavian Journal of Public Health 47: 87-89. doi: https://doi. org/10.1177/1403494819830340.

Olofsson, J. and E. Wadensjö (2015). Rätt och fel om ungdomsarbetslösheten [Right and Wrong concerning Youth Unemployment]. Stockholm: Dialogos.

Pawson, R. and N. Tilley (1997). Realistic Evaluation. London: SAGE.

Pyöriä, P., S. Ojala, T. Saari, and K.-M. Järvinen (2017). The Millennial Generation: A New Breed of Labour? SAGE Open. doi: https://doi.org/10.1177/2158244017697158.

Reneflot, A. and M. Evensen (2014). Unemployment and psychological distress among young adults in the Nordic countries: a review of the literature, International Journal of Social Welfare 23(1): 3-15. doi: https://doi.org/10.1111/ijsw.12000.

Rönnblad T., E. Grönholm, J. Jonsson, I. Koranyi, C. Orellana, B. Kreshpaj, L. Chen, L. Stockfelt and T. Bodin (2019). Precarious employment and mental health: a systematic review and meta-analysis of longitudinal studies, Scandinavian Journal of Work Environment and Health 45(5): 429-443. doi: https://doi.org/10.5271/sjweh.3797.

Ryan, G. W. and R. Bernard (2003). Techniques to identify themes, Field Methods 15(1): 85-109. doi: https://doi.org/10.1177/1525822X02239569.

Sayer, R. A. (1992). Method in Social Science: A Realist Approach, London: Routledge.

Sløk-Andersen, B. (2018). The Becoming of Good Soldiers. An Ethnographic Exploration of Gender and Other Obstacles in the Military Borderland. PhD dissertation, The Saxo Institute Faculty of Humanities, University of Copenhagen.

SOU (2016). En robust personalförsörjning av det militära försvaret. [A robust personnel supply for the Swedish military defense]. Swedish Government Report 2016: 63. https:// www.regeringen.se/4a8023/globalassets/regeringen/dokument/forsvarsdepartementet/ sou/en-robust-personalforsorjning-av-det-militara-forsvaret sou-201663.pdf.

Standing, G. (2011). The Precariat: the New Dangerous Class, London: Bloomsbury Academic.

Strand, S. (2019). (Re)Inventing the Armed Forces: A Governmentality Analysis of Swedish Military Marketing and Outreach in the Era of Voluntarism. PhD Thesis, Department of Global Studies, University of Gothenburg.

Swedish Agency for Public Management (2016). Sjukfrånvaron i staten år 2017. [Sickness absence in the government 2017]. Dnr 2018/59-5.

Swedish Armed Forces (2011). Annual Report 2010, Annex 2: Personnel. https://www. forsvarsmakten.se/siteassets/4-om-myndigheten/dokumentfiler/arsredovisningar/arsredovisning-2010/bilaga-2-ar-2010.pdf.

Swedish Armed Forces (2012). Försvarsmaktens instruktion med antagningsordning till grundläggande militär utbildning och kompletterande militär utbildning. [The Armed Forces instruction and admissions regulations for basic military training and complementary military training]. (HKV 16207:662 79: 2012-12-08). 
Swedish Armed Forces (2017). Annual Report 2016, Annex 1: Personnel. FM2016-17170:2. https://www.forsvarsmakten.se/siteassets/4-om-myndigheten/dokumentfiler/arsredovisningar/arsredovisning-2016/hkv-2017-02-21-bilagor-1-3-ar16.pdf.

Swedish Armed Forces (2020). Annual Report 2019, Annex 1: Personnel. FM2018:20355:12. https://www.forsvarsmakten.se/siteassets/4-om-myndigheten/dokumentfiler/arsredovisningar/arsredovisning-2019/fm2018-20355.12-forsvarsmaktens-ar-2019 bilaga-1-3.pdf.

Swedish Defence Commission (2019). The Swedish Defence Commission's White Book on Sweden's Security Policy and the Development of the Military Defence 2021-2025, Stockholm: Government Offices of Sweden. https://www.government.se/articles/2019/05/theswedish-defence-commission-presents-its-white-book-on-swedens-security-policy-andthe-development-of-its-military-defence/.

Swedish Social Insurance Agency (2018). Sick Leave at the Swedish Labour Market. Social Insurance Report 2018:2 [In Swedish, with an abstract in English]. https://www.forsakringskassan.se/wps/wcm/connect/5b9d37a9-a56d-4453-896f-fed299534d91/socialforsakringsrapport-2018-02.pdf? MOD=AJPERES\&CVID=.

Thornton, P. H., Ocasio, W. \& Lounsbury, M. (2012). The Institutional Logics Perspective: A New Approach to Culture, Structure, and Process, Oxford: Oxford University Press.

Tompa, E., H. Scott-Marshall, R. Dolinschi, S. Trevithick and S. Bhattacharyya (2007). Precarious employment experiences and their health consequences: towards a theoretical framework, Work 28(3): 209-224.

Twenge, J., M. A. Bell Cooper, T. E. Joiner, M. E. Duffy, and S. G. Binau (2019). Age, period, and cohort trends in mood disorder indicators and suicide-related outcomes in a nationally representative dataset, 2005-2017, Journal of Abnormal Psychology 128(3): 185-199. doi: https://doi.org/10.1037/abn0000410.

Vancea, M. and M. Utzet (2017). How unemployment and precarious employment affect the health of young people: a scoping study on social determinants, Scandinavian Journal of Public Health, 45(1): 73-84. doi: https://doi.org/10.1177/1403494816679555.

Ylistö, S. (2018). Why do young people give up their job search? Nordic Journal of Working Life Studies, 8(3): 27-45. doi: https://doi.org/10.18291/njwls.v8i3.109539.

Österberg, J. (2018). We Want You as Our New Recruit. Prerequisites for Recruitment to and Retention in the Swedish Army. PhD Thesis, Faculty of Art and Social Sciences. Karlstad University. http://kau.diva-portal.org/smash/record.jsf?pid=diva2\%3A1179930\& dswid $=5940$.

Österberg, J. and L. Rydstedt (2018). Job satisfaction among Swedish soldiers: Applying the Job Characteristics Model to newly recruited military personnel, Military Psychology, 30(4): 302-310. doi: https://doi.org/10.1080/08995605.2018.1425585.

\section{Note}

i According to the Swedish Defense Commission (2019), the current annual requirement is 4,400 people. 